\title{
(net) werken voor chronisch zieken
}

Citation for published version (APA):

Spreeuwenberg, C. (1994). (net) werken voor chronisch zieken. Maastricht University. https://doi.org/10.26481/spe.19941216cs

Document status and date:

Published: 16/12/1994

DOI:

10.26481/spe.19941216cs

Document Version:

Publisher's PDF, also known as Version of record

\section{Please check the document version of this publication:}

- A submitted manuscript is the version of the article upon submission and before peer-review. There can be important differences between the submitted version and the official published version of record.

People interested in the research are advised to contact the author for the final version of the publication, or visit the DOI to the publisher's website.

- The final author version and the galley proof are versions of the publication after peer review.

- The final published version features the final layout of the paper including the volume, issue and page numbers.

Link to publication

\footnotetext{
General rights rights.

- You may freely distribute the URL identifying the publication in the public portal. please follow below link for the End User Agreement:

www.umlib.nl/taverne-license

Take down policy

If you believe that this document breaches copyright please contact us at:

repository@maastrichtuniversity.nl

providing details and we will investigate your claim.
}

Copyright and moral rights for the publications made accessible in the public portal are retained by the authors and/or other copyright owners and it is a condition of accessing publications that users recognise and abide by the legal requirements associated with these

- Users may download and print one copy of any publication from the public portal for the purpose of private study or research.

- You may not further distribute the material or use it for any profit-making activity or commercial gain

If the publication is distributed under the terms of Article $25 \mathrm{fa}$ of the Dutch Copyright Act, indicated by the "Taverne" license above, 


\section{Universiteitsbibliotheek}

De uitleentermijn verstrijkt op:

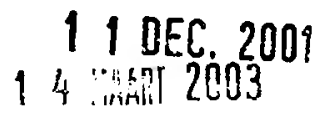
uitleentermijn aan te vragen.

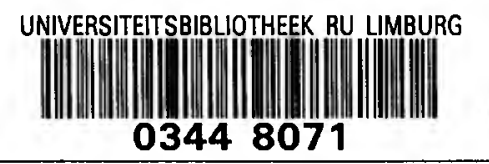




\title{
(NET) WERRBN VOOR CHRONISCH ZIEKEAN
}

\author{
Rede \\ uitgesproken bij de aanvaarding van het ambt van \\ bijzonder hoogleraar in de \\ 'Integratie van eerste- en tweedelijns geneeskundige zorg \\ voor chronisch zieke patiënten' \\ vanwege de stichting Wetenschapsbeoefening Limburg \\ in opdracht van de Adviesgroep voor \\ het stimuleringsprogramma Gezondheidsonderzoek \\ aan de \\ Rijksuniversiteit Limburg te Maastricht \\ op 16 december 1994 \\ door
}

DR C. SRREEUWEMBERG 
125 ge0450

Sibliotheel

R.U. Limburg 
Mijnheer de Rector Magnificus, Dames en Heren,

Verdoorn constateett in zijn studie over het Gezondheidswezen te Amsterdam gedurende de $19 \mathrm{e}$ eeuw dat de daling van de algemene sterfte omstreeks 1880 inzet. ${ }^{1}$ Dit is opmerkelijk laat, omdat in Amsterdam leidingwater reeds in 1854 was ingevoerd, de klinische onderzoekmethoden en maatregelen als anti- en asepsis al een halve eeuw eerder verbeterd waren en de op het medisch onderwijs en de geneeskundige praktijk betrekking hebbende wetten van Thorbecke uit 1865 stammen. Verdoorns verklaring voor de vertraging in de verbetering van het sterftecijfer is, dat de vooruitgang er weliswaar in theorie was, maar dat velen in de praktijk niet van deze verbeteringen konden profiteren. Zo kon lang niet iedereen zich de weelde van leidingwater veroorloven, zodat velen nog lang waren aangewezen op de zogeheten standpijpen. Traditionele opvattingen zorgden voor een sociaal-psychologisch klimaat waarin diffusie van de nieuwe verworvenheden werd tegengehouden. Deze situatie werd sterk in de band gewerkt door de inferieure kwaliteit van de medische zorg in de overheidsziekeninrichtingen, waardoor mensen er wel voor pasten zich te laten opnemen, zelfs wanneer dit nodig was.

Van deze ervaring kunnen we leren dat gezondheidsbeleid in rapporten als de 'Nota 2000' en de 'Volksgezondheid Toekomst Verkenning' terecht als determinant van de gezondheidstoestand van de bevolking wordt beschouwd: uiteindelijk hadden de maatregelen immers wel effect. ${ }^{2}{ }^{3}$ Een andere les is, dat beleid niet af is op het moment dat de overheid heeft gesproken en de beleidsvoornemens in de regelgeving zijn verwerkt. Beleid moet worden gedragen door de uitvoerders en door de bevolking en door praktische maatregelen worden geschraagd. Verdoorn laat zien, dat artsen die de gezondheidstoestand van hun patiënten willen optimaliseren niet kunnen voorbijgaan aan de structuur en de organisatie van de medische zorg.

Vanmiddag wil ik $U$ mijn leeropdracht 'Integratie van eerste- en tweedelijns geneeskundige zorg voor chronisch zieke patiënten' uitleggen. Deze leeropdracht kan niet los worden gezien van de door staatssecretaris Simons in 1990 uitgebrachte notitie 'Chronisch-Ziekenbeleid' waarin drie doelstellingen van beleid worden gemeld: ${ }^{4}$

1. Het bevorderen dat chronische ziekten en de gevolgen daarvan, door middel van preventie, verbetering van behandeling en palliatieve zorg, doeltreffend en doelmatig worden bestreden.

2. Het stimuleren van een situatie waarin mensen met een chronische aandoening de kwaliteit van leven als beter ervaren.

3. Het bevorderen van een leefbaarder maatschappelijk klimaat voor chronisch zieken. 
Deze doelstellingen gaan verder dan die van de geneeskundige zorg. Het is niet de taak van de medicus een leefbaar maatschappelijk klimaat te creēren. Zijn professionele bijdrage dient wel in een dergelijke brede optie te passen.

De staatssecretaris schreef, dat een blijvende "kunstmatige" scheiding tussen intra- en extramurale zorg tot afstemmingsproblemen zal leiden en dat chronisch zieken geen baat hebben bij een dergelijke scheiding. Hij wilde door beleid bereiken, dat het zorgaanbod zoveel mogelijk wordt afgestemd op de behoefte van de patiēnt en voorts wilde hij de huidige, meestal organisatorische knelpunten op dit terrein daarmee oplossen.

Simons wilde zorgmodellen ontwikkelen door te experimenteren met de opzet van een aparte functie transmurale zorg, opgezet door intra- en extramurale zorg. Hierbij dacht hij aan (mede)behandeling door huisarts en specialist samen, het beschikbaar stellen van enkele bedden aan huisartsen en de inzet van specialistische verpleegkundigen zoals reumaconsulenten en CARA-verpleegkundigen in de thuiszorg en de intramurale zorg of in specialistische behandelingscentra.

Simons spitste hiermee de eerdere ideeën van de commissie-Dekker over substitutie en een functionele zorg toe op de groep chronisch zieken.

Op grond van de notitie 'Chronisch-Ziekenbeleid' is in 1991 de Nationale Commissie Chronisch Zieken (NCCZ) ingesteld, onder meer om behulpzaam te zijn bij het oplossen van problemen in het veld. Door de zorgvraag en het zorgaanbod voor chronisch zieken te bespreken, wil ik de achtergrond van deze problemen schilderen en daarna dieper ingaan op enige suggesties die staatssecretaris Simons in zijn notitie heeft gedaan.

\section{CHRONISCH(E) ZIEK(T)EN}

Hèt kenmerk van chronisch zieken is, dat mensen langdurig ziek zijn. Arbitrair wordt hiervoor in de somatiek zes maanden en in de psychiatrie enkele jaren aangehouden. Over de inclusie van elementen als ernst, zorgbehoefte en zorgbeslag in de definitie van chronische ziekten wordt echter verschillend gedacht. ${ }^{5}$ o 7 De NCCZ omschrijft chronische ziekten als onomkeerbare aandoeningen, zonder uitzicht op volledig herstel en met een gemiddeld lange ziekteduur.

Een chronische ziekte zou zich van een handicap onderscheiden door de mate van activiteit van het ziekteproces en de aanwezigheid van een zekere progressie. ${ }^{8}$ Toch hoeft $\mathrm{U}$ alleen maar aan het voorbeeld van de hooikoorts te denken om te weten dat een jarenlang periodiek voorkomende aandoening geen progressie behoeft te vertonen en zelfs uiteindelijk kan verdwijnen. Dat een aandoening op een gegeven moment als 'chronisch' wordt beschouwd, wil niet zeggen dat die ziekte altijd van het stempel 'chronisch' mag worden voorzien. Malaria en tuberculose zijn bedreigende chronische aandoeningen geweest. Nu er effectieve medicijnen zijn, zou het niet juist zijn om deze in Nederland in alle gevallen als een chronische ziekte te beschouwen. Chronische aandoeningen zijn aandoeningen waarbij we nog onvoldoende vat hebben op het onderliggend pathofysiologisch mechanisme of waarvoor nog geen effectief medicijn bestaat. 
$\mathrm{Nu}$ hebben definities een bepaald gebruiksdoel. Wordt bijwoorbeeld geprobeerd chronische ziekte te definjëren met het $o$ g op de vraag wie er recht hebben op een uitkering, dan kan niet om duur, ernst en functieverlies heen worden gegaan. Om elkaar te verstaan lijkt het vruchtbaarder te zijn een brede definitie van chronische ziekte te hanteren en vervolgens naar gelang het gebruiksdoel een nadere specificatie aan te brengen.

\section{VRAAG EN AANBOD}

Het is fraai om zorgvraag en zorgaanbod te willen scheiden, maar deze twee factoren zijn intens met elkaar verweven. Zo wordt er in het WHO-programma 'Health for all by the year 2000' voor gepleit om de vraag door preventie, vroege herkenning en adequate behandeling terug te dringen. Chronische ziekten confronteren ons ermee dat de werkelijkheid er wel eens anders uitziet dan we graag zouden willen. Eén van de hoofddoelstellingen van 'Health for all' is de periode van het leven waarin mensen vrij van ziekte of invaliditeit zijn met $10 \%$ te verlengen. ${ }^{10}$ " Die duur is thans voor zowel mannen als vrouwen 60 jaar en zou dus tot 66 jaar moeten worden opgeschroefd. In een recente Nederlandse rapportage over de stand van zaken wordt wijselijk gezwegen over het vooruitzicht dat deze doelstelling kan worden gehaald. ${ }^{12}$

Wat zit hier achter? Met de levensverwachting is immers niets mis. Deze bedroeg in 1990 voor mannen 73,8 jaar en voor vrouwen 80,1 jaar en volgens een prognose van het CBS bedraagt ze in 2010 voor mannen 1,2 jaar en voor vrouwen 1,4 jaar meer dan nu. Ons probleem is echter de jaren vrij van ziekte en invaliditeit te verlengen. Er zijn weinig tekenen dat de compressie van morbiditeit - dus het terugdringen van de periode dat mensen ziek zijn -, waarop jemand als Fries optimistisch rekende, de eerstkomende jaren zal optreden. ${ }^{13}$ 14 15 Integendeel, we moeten er rekening mee houden dat de expansie van morbiditeit nog lang zal voortduren. Dit betekent, dat mensen ouder worden zonder dat het aantal jaren dat mensen gezond doormaakt navenant toeneemt. Dit komt onder meer door een schijneffect: ziekten worden door onze verbeterde technologische mogelijkheden in een vroeger stadium vastgesteld, terwijl onze mogelijkheden om mensen afdoende te behandelen ten opzichte van de verbeterde diagnostiek ver achterblijven. Mensen lijken dus langer ziek te zijn. En, hoewel dit nog niet hoeft te betekenen dat men zich langer ziek voelt en de kwaliteit van leven door als ziek bestempelden heel uiteenlopend wordt ervaren, betekent alleen al het feit dat meer mensen als chronisch zieken worden aangemerkt dat de druk op de gezondheidszorgvoorzieningen toeneemt.

Voor de lange termijn verwacht ik, dat de snel groeiende kennis op het gebied van de immunologie en de celbiologie tot opzienbarende doorbraken zal leiden, niet alleen om chronische ziekten te diagnostiseren maar ook te genezen of de negatieve effecten lang uit te stellen.

De eerste vijftien jaar mogen we hier nog niet op rekenen. Verwacht wordt, dat in 2010 de prevalentie van het aantal mensen met een chronische aandoening met 20 'n 30 à 40 percent zal zijn toegenomen (zie tabel 1 ). 
Tabel 1. Toename tussen 1990 en 2010 van het aantal lijders aan enkele chronische ziekten per 1000 inwoners.

$\begin{array}{ll}\text { gewrichtsslijtage } & 35 \% \\ \text { CARA } & 23 \% \\ \text { slechthorendheid } & 34 \% \\ \text { suikerziekte } & 54 \% \\ \text { depressie } & 24 \% \\ \text { hartinfarct } & 34 \% \\ \text { staar } & 33 \% \\ \text { beroerte } & 35 \% \\ \text { dementie } & 39 \%\end{array}$

Bron: RIVM. Volksgezopdheid Toetomstrentearing

\section{ZORGVRAAG}

Aan de verwachte stijging van het aantal chronisch zieken draagt de veranderende demografische opbouw van de bevolking ten gevolge van de dubbele vergrijzing fors bij. Dubbele vergrijzing komt doordat mensen ouder worden en er thans relatief minder kinderen worden geboren. Het relatieve aandeel van bejaarden zal dus steeds meer toenemen. Met de leeftijd neemt de kans toe op een chronische ziekte en dus stijgt met de disproportionele toename van het aantal ouderen tevens het aantal chronisch zieken. Juist bij ouderen groeit de betekenis van het fenomeen co-morbiditeit (zie tabel 2). ${ }^{16}$

Tabel 2. Aantal chronische aandoeningen per persoon volgens consultregistraries in hwisartspraktijken bij mensen jonger en ouder dan 65 jaar.

\begin{tabular}{|c|c|c|}
\hline aantal & $<65$ jaar & 265 jaar \\
\hline \multirow[t]{2}{*}{ chronische aandoeningen } & $N=21.349$ & $N=2.185$ \\
\hline & $\%$ & $\%$ \\
\hline geen & 95.9 & 76,9 \\
\hline éen & 3.8 & 19.5 \\
\hline twee & 0.3 & 3.2 \\
\hline drie & $<0,1$ & 0,3 \\
\hline vier & - & $<0,1$ \\
\hline
\end{tabular}

Bron: F.G. Scbellevis. 1993 
Co-morbiditeit is het verschijnsel dat bij iemand meer dan één chronische ziekte tegelijk voorkomt. Co-morbiditeit is gemakkelijker te constateren dan te interpreteren. Chronische ziekten als diabetes mellitus en reumatoīe arthritis tasten meer dan eén orgaansysteem aan. Bij deze ziekten is het optreden van co-morbiditeit vaak terug te voeren tot het normale, vooraf te voorspellen, beloop. Voorts kan belasting van het ene orgaan leiden tot aantasting van het andere. Chronische obstructieve longaandoeningen als chronische bronchitis en emfyseem belasten het hart, wat op den duur vaak tot hartproblemen leidt. Co-morbiditeit kan ook het gevolg zijn van een (eerdere) behandeling, zoals bestraling of chemotherapie. Co-morbiditeit kan verder optreden omdat een ziekte eerder wordt 'ontdekt' vanwege de omstandigheid dat een chronische patiënt onder medische behandeling staat of door het al genoemde verschijnsel dat onze diagnostiek zo sterk is verbeterd. Tenslotte kunnen mensen door endo- of exogene oorzaken vatbaarder zijn voor ziekten.

In samenhang met de vergrijzing van de bevolking is met de toename van chronische ziekten tevens een toename van co-morbiditeit te verwachten. ${ }^{17}$ Meer co-morbiditeit leidt tot een grotere zorgvraag.

Het is wat al te simpel om te stellen dat toename van de leeftijd leidt tot meer chronisch zieken en dat dit weer leidt tot een grotere zorgvraag. Zo is er zowel in Groot-Brittanniē als in ons land een verband aangetoond tussen het voorkomen van chronische ziekten enerzijds en sociaal-economische status en geslacht anderzijds. ${ }^{18} 1920$ Als voor de bevolkingssamenstelling wordt gecorrigeerd, komen er in de welvarender Amsterdamse buurten minder chronisch zieken voor dan in de minder welvarende. En ook de gevolgen van het chronisch ziek-zijn hangen van iemands sociaal-economische positie af.

Een chronische ziekte blijkt mensen lichamelijk, sociaal èn psychisch te belasten. Sociaal verkeren mensen met een chronische ziekte, post of propter, nogal eens in een achterstandpositie. Generalisatie van deze verschijnselen is echter weer onjuist. Immers, de lichamelijke, psychische en sociale beperkingen ten gevolge van een chronische ziekte verschillen van ziekte tot ziekte en tussen de lijders aan een zelfde ziekte, zoals Van den Bos liet zien voor patiēnten met diabetes mellitus en met een beroerte tussen de 55 en 80 jaar. ${ }^{21}$

Niet alleen verschilt de lichamelijke, psychische en sociale problematiek, ook het belang dat chronisch zieken aan de te onderscheiden problemen hechten en de preferenties die zij ten aanzien van de zorg hebben, lopen sterk uiteen. De een wil zo lang mogelijk zelfstandig blijven en zelf zijn of haar beslissingen nemen, terwijl de ander hulp en advies op prijs stelt.

De variëteit in problemen en preferenties speelt bij chronische aandoeningen een grotere rol dan bij acute aandoeningen. Vandaar dat juist bij de zorg aan chronisch zieken een beleidsdoel als 'zorg op maat' zwaar gaat wegen. 


\section{ZORGAANBOD}

Hoe reflecteen zich de zorguraag nu in het aanbod? Van den Bos berekende voor Amsterdammers van 55 tot 80 jaar de kans om gebruik te moeten maken van een zorgvoorziening (tabel 3).

Voor chronisch zieken is de kans op contact met medische voorzieningen zeven maal, op revalidatie vijf maal en op verpleging en verzorging vier maal hoger dan die voor een vergelijkbare groep niet chronisch zieken. ${ }^{22}$

Met de leeftijd neemt bij chronisch zieken de afhankelijkheid van professionele hulp toe (tabel 4). Het percentage chronisch zieken dat informele hulp krijgt neemt echter met de leeftijd niet toe. Waarschijnlijk komt dit omdat voor de informele zorg de grenzen al zijn bereikt!

De toegenomen zorgvraag blijkt uit macro-gegevens, zoals het aantal verrichtingen: tussen 1981 en 1992 heeft er in de ziekenhuizen een zorgverzwaring plaatsgehad van gemiddeld $1,6 \%$ en bij de wijkverpleging van $7,4 \%$ op jaarbasis. ${ }^{23}$ Bij de wijkverpleging is het aandeel van de jongere categorieën verminderd ten koste van de 80-plussers: van 1975 tot 1992 is het aandeel van 65 -plussers gestegen van $16,7 \%$ naar $31,4 \%$.

Tabel 3. Gebruik van een zorgvoorziening voor Amsterdammers ussen de 55 en 80 jaar.

$$
\text { medische zorg revalidatie verpleging e/o verzorging }
$$

met chronische aandoening

zonder chronische aandoening

odds ratio

\section{$79 \%$}

$33 \%$

7

$16 \%$
$4 \%$
5

5
$10 \%$

$3 \%$

4

Bron: G.A.M. van den Bos, 199 l

Tabel 4. Gebruik van informele en professionele hulp bij Amsterdanmers russen de 55 en 80 jaar (in percenten).

informele hulp

16

16

14

16

19 professionele hup

$\begin{array}{lrr}55-59 \text { jaar } & 16 & 2 \\ 60-64 \text { jaar } & 16 & 4 \\ 65-69 \text { jaar } & 14 & 6 \\ 70-74 \text { jaas } & 16 & 9 \\ 75-79 \text { jaar } & 19 & 17\end{array}$


Terwijl de inspanningen van de geneeskunde qua middelen en menskracht vooral uitgaan naar chronisch zieken, is de organisatie van de gezondheidszorg afgestemd op de acute zieken (zie schema). ${ }^{24}$ Dit is vreemd, want behoudens in de groep zeer jonge kinderen overreft het aantal chronische ziekten die van het aantal acute ziekten altijd. ${ }^{25}$

Zou het zorgstelsel worden afgestemd op de zorguraag van chronische zieken, dan zou de organisatie van de zorg breder moeten worden georiënteerd. Nu is dat zelfs voor de somatische aspecten niet het geval. Als aandoeningen als CARA en diabetes mellitus een zo vast patroon aan co-morbiditeit hebben, dan is het toch wel vreemd dat mensen met al de betrokken deelspecialisten aparte afspraken moeten maken.

Er moet meer aandacht bestaan voor het functioneren van de zieke dan voor het alleen behandelen van de ziekte. In vergelijking met de acute aandoeningen neemt technologie veelal een minder prominente plaats in. Voor de chronische zorg is het belangrijk dat de zorgsystemen op elkaar aansluiten en 'zorg op maat' bevorderen. De hinder ten gevolge van de zjekte is niet altijd even groot: daarom moeten exacerbaties adequaat worden opgevangen.

Het gaat echter niet alleen om genezing en medische behandeling, maar ook om zorg, opvang en begeleiding. In de zorg dient aandacht te bestaan voor de uiteenlopende problemen ten gevolge van het chronisch ziek-zijn.

Niet alle zorg kan professioneel worden gegeven. Daarom moet het thuisfront worden ondersteund en sociale steun worden geregeld. ${ }^{26}$ Waar mogelijk moet worden getracht de behandeling in de eigen omgeving te geven.

Schèna. Kenmerkende verschillen tussen acute en chronische zorg.

ACUTE ZORG

orientatie op ziekte

'iigh tech"

korte-termijn

episode-gebonden

cure

een-dimensionaal

professioneel

instelling

\section{CHRONISCHE ZORG}

orientatie op functie

'bigh touch'

continuiteit

cyclisch

care

multidimensionaal

familie/vnijwilliger

thuis

Phy noar: D., Kodber, 1994 


\section{ZORGVERNIEUWING}

Al deze gedachten hebben meegespeeld in de zorgvernieuwing die het vorige kabinet in zijn vaandel had staan. Een antal voorstellen had betrekking op wat in de notitie 'Chronisch-Ziekenbeleid' de "kunstmatige" scheiding tussen intra- en extramurale zorg wordt genoemd.

De geneeskundige hulpverlening aan chronisch zieken geschiedt door zowel huisartsen als specialisten. Soms door huisants of specialist, vaak ook door huisarts èn specialist (tabel 5).

Wordt de scheiding nu "kunstmatig" en "problematisch" geacht, deze is de afgelopen twintig jaar wel bewust vanuit 'Den Haag' gestimuleerd. Het gevolg is dat de reeds langer bestaande verschillen tussen de eerste en de tweede lijn zijn bestendigd. Huisartsen en specialisten verschillen in de plek waar zij werken, de wijze waarop patiënten instromen, de methode volgens welke zij diagnoses stellen en patiënten behandelen, en de systematiek van honorering.

Huisartsen en specialisten functioneren in twee behoorlijk gescheiden subsystemen of circuits. Binnen de intra- en extramurale circuits worden allerlei activiteiten ondernomen op het gebied van omschrijving van functie en takenpakket, kwaliteitsborging en standaardisering en samenwerking met andere disciplines. Deze zijn dan wel beperkt tot die uit het eigen circuit. ${ }^{27} 28$

Huisartsen en specialisten hebben nog weinig ondernomen om een gemeenschappelijke visie op de patiëntenzorg te ontwikkelen. Met visie bedoel ik niet zo zeer theoretisch gepraat over een ideale, maar nooit bereikbare situatie als wel de standpunten die blijken uit het concreet bespreken van een casus of een gezamenlijk protocol.

Tabel S. Zorggebruik van Amsterdanmers tussen de 55 en 80 jaar.

$\begin{array}{lccc} & \text { zorggebruik } & \text { huisarts } & \text { specialist } \\ \text { chronische bronchitis } & 69 & 56 & 39 \\ \text { suikerziekte } & 84 & 57 & 58 \\ \text { reuma of gewrichtsklachten } & 68 & 54 & 35 \\ \text { hartklachten } & 79 & 51 & 55 \\ \text { CVA (+ gevolgen) } & 74 & 39 & 46 \\ \text { kanker } & 78 & 49 & 63 \\ \text { ziekten van het zenuwstelsel } & 89 & 56 & 56\end{array}$

Bron: G.A.M. ven den Bos. 1991 
Dat de aansluiting van de circuits te wensen overlaat en dat deze discontinuiteit voor de betrokken patiēnten leidt tot aantasting van de verschillende aspecten van kwaliteit van leven, blijkt uit een recente door het NWO-programma 'Kwaliteit van zorg' geïnitieerde studie. ${ }^{29}$

Wellicht spelen misverstanden over het begrip 'continuīteit' een rol. Dit begrip voeren huisartsen al sinds de jaren vijftig in hun vaandel. Mij komt het voor, dat hiermee aanvankelijk is bedoeld dat huisartsen zich als persoon continu beschikbaar houden voor de patiënt. Tegenwoordig spreekt het echter niet meer zo vanzelf wat onder continuĩteit moet worden verstaan. Moet de huisarts altijd beschikbaar zijn?; moeten bepaaide categorieën patiènten, zoals stervenden, altijd een beroep op hem kunnen doen?; moet hij de beschikbaarheid van een huisarts kunnen garanderen?; heeft hij ook een taak voor opgenomen of poliklinisch behandelde patiēnten, of moet hij verzekeren dat huisartsgeneeskundige zorg aansluit op de zorg vanuit instellingen en vice versa? ${ }^{30}$

Voor de patiênt die een gang door de gezondheidszorg moet maken ligt deze laatste aansluiting in ieder geval problematisch. ${ }^{31}{ }^{32}$ De huisarts Querido benoemde de discontinuïteit tussen de eerste en de tweede lijn zelfs met het woord 'breuk' ${ }^{33} \mathrm{Hij}$ laat zien hoe de chronjsche patiënt met uiteenlopende hulpverleners met een medische en nietmedische achtergrond te maken heeft. De behandeldoelen en -wijzen sluiten slecht op elkaar aan en de rechterhand weet niet wat de linker doet. ${ }^{34}{ }^{35}$ Kortom, er is te weinig complementariteit.

Indien de behandeldoelen en -wijzen uiteenlopen door verschillen in kennis, dan is er een aangrijpingspunt om er jets aan te doen. Wat dit betreft is het gunstig dat de huisarts in de jaren tachtig meer waarde is gaan hechten aan zijn medische taken. Problematisch wordt het als de corzaak een uiteenlopende visie op de geneeskundige zorg is, zoals in het verleden bleek bij de behandeling van patiënten met reumatoïde arthritis en recent bij de behandeling van hypercholesterolemie en preventie van osteoporose. ${ }^{36}{ }^{37} 38$

Een verschillende kijk op zorg tussen de intra- en extramurale zorg is niet uitsluitend een Nederlands probleem. Nog onlangs hebben de Engelse autoriteiten "the key players" opgeroepen hun "values, aspirations and constraints" te formuleren en deze te integreren "by the process of listening, understanding and compromise". ${ }^{39}$ De vraag is of dit wel kan en of een generalistische versus een gespecialiseerde oriëntatie wel tot gemeenschappelijkheid kan leiden. Dat hier een probleem ligt, wordt ook in de Verenigde Staten herkend. Met het oog hierop pleiten de Amerikaanse Board of Family Practice en de Board of Internal Medicine zelfs voor een nieuw type specialist, de generalist physician, die de traditionele internist en 'family physician' in zich verenigt en daarvoor specifiek wordt opgeleid. ${ }^{40}$

Naast inhoudelijke verschillen tussen eerste en tweede lijn worden aansluiting en samenwerking gehinderd door het totaal verschillend organisatorisch verband waarbinnen 
wordt gewerkt. Specialisten werken in maatschappen en in ziekenhuizen. In de ziekenhuissector doen zich al jaren concentraties voor. Alleen al de laatste zes jaar is het aantal erkende ziekenhuizen afgenomen van 191 tot $157 .^{41}$ Door deze concentratie, de daarmee gepaard gaande groei in middelen voor het ziekenhuis en de voortgaande integratie van het medisch beleid in dat van het ziekenhuis, kunnen ziekenhuizen strategisch opereren.

Tegenover de tweede lijn staat een verbrokkelde eerste lijn, met uiteenlopende aanbieders als knisverenigingen, gezinszorg en huisartsen. De kruisverenigingen en de gezinszorg hebben een nog forsere concentratie doorgemaakt dan de ziekenhuizen. In vergelijking hiermee vormen de huisartsen een oase van rust. Nog steeds werkt meer dan de helft van de huisartsen als solist; ongeveer énn-derde werkt in een gezondheidscentrum of groepspraktijk en de overigen in een duo-praktijk. De Landelijke Huisartsen Vereniging (LHV) probeert met alle macht het veld te versterken, bijvoorbeeld door het creëren van een heldere organisatie met als basis de huisartsengroepen, maar moet in haar beleid rekening houden met de grenzen van wat haalbaar is voor huisartsen. Gaande de opbouw van de huisartsgroepen hebben huisartsen zich teruggetrokken op hun kerntaken: ze voeren deze kerntaken kwalitatief steeds beter uit, maar willen of kunnen minder aandacht besteden aan samenwerking met de tweede lijn. Het lijkt erop dat voor dit moment de grens aan de spankracht van huisartsen bereikt is."2 Deze prioritering is begrijpelijk, maar doet wel vraagtekens rijzen bij de haalbaarheid op korte termijn van beleidsdoelstellingen als substitutie, versterking van de poortwachtersfunctie en transmurale zorg. Desondanks wil ik deze doelstellingen toelichten.

\section{SUBSTITUTIE}

Substitutie is onder meer an de orde gekomen in het rapport van de commissieDekker. ${ }^{43}$ Het betreft het streven om de verantwoordelijkheid voor en de uitvoering van zorg zodanig te verschuiven dat deze wordt verleend op het laagste niveau waar dit verantwoord kan. Dit laatste kan inhouden dat zorg op een hoger niveau moet worden uitgevoerd dan thans geschiedt. Toch is het reëel substitutie niet als een neutrale operatie te beschouwen. Substitutie wordt nagestreefd om de collectieve lastendruk te beperken, de kosten te beheersen en de doelmatigheid in de zorgverlening te vergroten. ${ }^{44}$ Randvoorwaarden zijn dat de doelstellingen en de daaraan gerelateerde functies van de voorziening blijven gehandhaafd.

Tot nu toe heeft de nadruk vooral gelegen op de verschuiving van zorg van de specialist naar de huisarts, dus tussen artsen. De vraag of binnen de genoemde voorwaarden ook zorg verschoven kan worden van de hogere naar de lagere gekwalificeerde professional, is nog te weinig gesteld. Ik zou horizontale substiturie, zoals verschuiving van de tweede naar de eerste lijn, willen onderscheiden van verticale substitutie, zoals van de arts naar de verpleegkundige of de praktijkassistente. ${ }^{45} 46$ 
Op het gebied van chronische ziekten als reuma en diabetes mellitus zijn goede ervaringen opgedaan met verticale substitutie."

Al enige jaren worden in Rotterdam diabetesverpleegkundigen volgens het werkmodel van de trombosediensten met succes ingeschakeld om oraal behandelde doch metabool slecht ingestelde diabeten van het type II over te zetten op insuline. ${ }^{\text {s }}$ In veel ziekenhuizen regelt de diabetesverpleegkundige onder supervisie van een arts de instelling op insuline. Waarom zou een verpleegkundige geen anamnese kunnen afnemen en cenvoudig onderzoek kunnen verrichten zoals de bepaling van gewicht en bloeddruk en het controleren van de voeten en arteriële pulsaties? Door haar specialisatie op het gebied van diabetes en haar andere sociale positie, is een diabetesverpleegkundige vaak gemakkelijker in staat met de patiënt te communiceren en 'compliance' te bewerkstelligen.

Nieuwenhuijzen Kruseman heeft op deze plaats aangegeven dat de gezondheidszorg voor het dilemma staat meer zorg voor minder geld te moeten leveren. ${ }^{49}$ Realistisch schat hij in dat de dure zorg door medisch specialisten moet wijken voor goedkopere vormen van zorg. Sprekend over de vraag of de huisarts of de diabetesverpleegkundige de zorg aan tot nu toe poliklinisch behandelde diabeten moet geven, vindt hij het meer voor de hand liggen de diabetesverpleegkundige een meer centrale plaats toe te bedelen. In de diabeteszorg kan een groot aantal verrichtingen bij goede training immers door een diabetesverpleegkundige worden uitgevoerd. De diabelesans kan een meer adviserende rol krijgen en kan zich daardoor meer concentreren op het behandelen van bedreigende complicaties.

In het model dat binnen het Academisch Ziekenhuis in Groningen is ontwikkeld, functioneert de reumaconsulente als 'case-manager' en voert zij taken uit op het gebied van voorlichting, advisering, begeleiding en verwijzing. Behandeling van de ontsteking en de pijn en het handhaven van de gewrichtsfuncties is de taak van een arts. De functie reumaconsulente wordt dọr zorgverleners en patiënten zeer gewaardeerd. ${ }^{\text {so }}$

Ik kan me voorstellen, dat ten aanzien van de poliklinisch en in de eerste lijn behandelde patiënten in een stabiele fase van chronische aandoeningen als diabetes mellitus, reuma, CARA, neurologische aandoeningen en kanker eens kritisch wordt nagegaan hoe het zorgproces er thans uitziet en welke de argumenten er voor het huidig schema voor behandeling en controle zijn en dat voorts wordt bezien in welke gevallen de patiēnt bij de arts moet komen en wanneer inschakeling van een verpleegkundige als eerst aanspreekbare functionaris thuis of in het ziekenhuis verantwoord is.

Voorlopig zie ik als voordelen de bredere oriëntatie op zorg en begeleiding, de beperkte medische kennis en vaardigheden die voor behandeling in de stabiele fase en het herkennen van stoornissen noodzakelijk is, een geringere kans op inductie van overbodige medische zorg en - hoewel ik daarvan geen overspannen verwachtingen heb - geringere kosten. 
De voorwaarden voor een dergelijke heroriëntatie worden gunstiger door allerlei ontwikkelingen binnen de verpleegkunde in de richting van differentiatie en specialisatie. ${ }^{\text {st }}$ sz Zowel thuis als in het ziekenluis werken verpleegkundigen die zelfstandig spreekuren doen en een consultatiefunctie hebben jegens andere professionele hulpverleners. ${ }^{53}$ s4 ${ }^{5 s}$ in de Angelsaksische landen verzorgen de intramuraal actieve 'clinical nurse specialist' en de extramuraal werkende 'nurse practitioner' de directe patiëntenzorg. De laatste heeft een grote mate van autonomie en heeft - net zo als de verloskundige - het recht bepaalde medicijnen voor te schrijven.

Natuurlijk moei er aan voorwaarden betreffende opleiding, verantwoordelijkheid, protocollering, supervisie en bevoegdheid worden voldaan. Wat dit laatste betreft biedt de nieuwe wet BIG meer mogelijkheden.

\section{POORTWACHTERFUNCTEE}

Naast substitutie is de versterking van de poortwachterfunctie van de huisarts sinds het rapport van de commissie-Biesheuvel een beleidsdoelstelling. ${ }^{56}$ Helaas wordt deze doelstelling nog mager uitgewerkt. In Nederland kennen we voor alle ziekenfondsverzekerden en de meeste particulier verzekerden immers al jaren een verwijssysteem. De Nederlandse huisartsgeneeskunde heeft haar sterke positie hieraan te danken. Ook in het Verenigd Koninkrijk moeten patiënten worden verwezen; daar heeft de huisarts nog mér de functie van poortwachter, doordat het aantal specialisten verhoudingsgewijs laag is en huisartsen selecteren wie van de wachtlijst voorrang moet hebben. In het Amerikaanse HMO-systeem wordt de term 'gate keeper' niet alleen gebruikt om te bepalen wie naar de tweede lijn mag worden verwezen, maar ook om degene die daar niet (meer) thuishoort te verwijderen. Een dergelijke taak reikt verder dan de zeeffunctie en de gids- en tolkfunctie van de huisarts waarover Van Es jaren geleden al sprak. ${ }^{57}$

Instrumenten om te zorgen dat de patiënt niet onnodig in de tweede lijn verblijft, zijn een goede vraagstelling, de bewaking van het antwoord daarop en een zekere protocollering van de toegang tot de tweede lijn. Een voorbeeld van dit laatste is het CARA-protocol zoals dat in Eindhoven en Tilburg wordt gehanteerd. ${ }^{58} 59$ Met de jaarlijkse vernieuwing van de herhaalkaart heeft de huisarts voor ziekenfondsverzekerden theoretisch het instrument in handen om patiënten terug te krijgen in de eerste lijn. Huisartsen maken hiervan weinig gebruik. Voor zover het om een eenzijdige beslissing van de huisarts gaat, ben $i k$ het hiermee eens. Het komt het concept van samenwerking niet ten goede als huisartsen buiten patiēnt en specialist om zouden kunnen bepalen wie wel of niet onder specialistische behandeling kan blijven. Ook van patiēntenzijde wordt bezwaar gemaakı tegen een cipiersfunctie van de huisarts. ${ }^{\circ}$ Wel zou de huisarts vaker met de specialist en de patiēnt kunnen bespreken of verblijf in de tweede lijn nog nodig is en of hij de behandeling geheel of gedeeltelijk kan overnemen. Dit komt overeen met het zorgsturend vermogen dat de LHV verder wil ontwikkelen. ${ }^{61}$ 


\section{TRANSMURALE ZORG}

Tenslotte het beleidsdoel transmurale zorg, dat ook al door de commissie-Biesheuvel is genoemd. Het begrip 'transmurale zorg' is typisch gebonden aan het Nederlandse gezondheidszorgsysteem. Dit begrip opzoeken in de internationale literatuur is weinig vruchtbaar, want bij invoering van het keyword 'transmural' in een terminal verschijnt er op het scherm wel allerlei informatie over de hartspier, maar niet over de organisatie van de gezondheidszorg.

Letterlijk gaat het om de zorg die de muur tussen de eerste en tweede lijn doorbreekt. Van der Grinten definieert transmurale zorg als "de vormen van medische, paramedische en verpleegkundige zorgverlening die zich bevinden op het continuüm tussen de uitersten van generalistische en specialistische zorg, en die de resultante zijn van samenwerking en afstemming tussen de generalistische en specialistische zorgverleners op basis van gemeenschappelijk gedragen verantwoordelijkheid met expliciete deelverantwoordelijkheden". ${ }^{62}$

Niet alle zorg die vanuit het ziekenhuis buiten het ziekenhuis wordt gegeven, valt onder het begrip 'transmurale zorg'. Van transmurale zorg is geen sprake als een ziekenhuis zonder medeverantwoordelijkheid van de extramurale sector buiten het ziekenhuis diensten aanbiedt. Transmurale zorg verschilt derhalve van ziekenhuisverplaatste zorg door het feit dat transmurale zorg gebaseerd is op samenwerking tussen en afspraken met generalistische en specialistische zorgverleners.

Een nieuw argument voor transmurale zorg is de opmars van de mogelijkheden thuis medische technologie toe te passen. Het NHG heeft al richtlijnen voor infuustechnieken, parenterale pijnbestrijding, antibiotica per infuus, cytostatica, parenterale voeding, sondevoeding, zuurstoftoediening, vernevelen, ascitespunctie, nazorg na pleurapunctie, catheteriseren en decubitusbestrijding. ${ }^{63}$ Bij technieken kan de extramurale sector vanuit het ziekenhuis worden ondersteund. Het infuusproject hier ter plaatse werkt vanuit een dergelijk model. De integrale kankercentra hebben een richtijn voor de indicatie, toediening en organisatie van infusietechnieken bij pijnbehandeling thuis uitgebracht, gecompleteerd met een checklist voor wederzijdse overdracht en een extramurale vragenlijst voor pijn. ${ }^{64}$

Als andere argumenten voor het creëren van transmurale zorg worden wel genoemd:

- bijdragen aan substitutie naar een goedkopere zorgvorm;

- verzekeren van continuiteit;

- behandelen in de eigen omgeving van de patiënt;

- creëren van grotere flexibiliteit;

- bijdragen aan ontmedicalisering.

Door transmurale zorg kunnen zorgvragen gemakkelijker functiegericht worden benaderd. 


\section{FINANCIERING}

De laatste jaren zijn allerlej beleidsvoornemens van de overheid mank gegaan vanwege gebrekkige financiering. Veelal is er geen gebrek aan geld voor experimenten. Zeker op het gebied van zorgvernieuwing kregen duizend - en zelfs meer - bloemen de gelegenheid te bloeien. Deze experimenten laten zien dat men in ons land op de werkvloer actief bezig is met de positie van chronisch zieken. ${ }^{6 s}$ Veel experimenten lopen echter dood door organisatorisch falen en gebrek aan implementatiemogelijkheden en reguliere financiering. Dit doet zich ook voor bij op zich geslaagde experimenten. ${ }^{66}$

De oorzaak hiervan is een algemeen probleem om de gezondheidszorg te financieren, een specifiek probleem om in een oud systeem nieuw geld vrij te maken, en dit heeft weer te maken met de rigiditeit van ons stelsel van gezondheidszorgvoorzieningen.

Hoewel over de mate waarin en de wijze waarop verschillend wordt gedacht, is er communis opinio dat de kosten van de gezondheidszorg - thans zo'n 60 miljard gulden per jaar - moeten worden beheerst. De eerder geschetste autonome ontwikkeling van de zorgvraag, de daarbij nog komende effecten door de gestegen mondigheid van patiënten, zoals blijkt uit een toenemende vraag om een 'second opinion', en de voortschrijdende medische technologie induceren immers een toename van het aantal verrichtingen, zowel intra- als extramuraal. Tussen 1982 en 1992 heeft de sector deze stijging van de vraag opgevangen door een produktiviteitsstijging van $0,6 \%$ per jaar te bewerkstelligen. Van der Zwan bevestigt, dat er nauwelijks meer mogelijkheden tot produktiviteitsstijgingen zijn. ${ }^{67}$ Dit veroorzaakt een ernstig probleem. Verwacht wordt dat de niet voor de inflatie gecorrigeerde uitgaven in de intramurale sector de komende jaren met $5,1 \%$ zullen stijgen, terwijl het FOZ $19951,4 \%$ minder toestaat. Zelfs als het kabinet de in het regeerakkoord achter de hand gehouden $0,5 \%$ zou voteren, blijft er een tekort. Nu iedereen alle zeilen moet bijzetten om de zorg waarom nu wordt gevraagd te kunnen verlenen, is er niet gemakkelijk nimte voor nieuwe initiatieven. Aan dergelijke nieuwe ontwikkelingen zitten immers risico's.

Hierbij komt het specifieke probleem dat de ziekenhuissector, de thuiszorg, de specialisten en de huisartsen gescheiden budgetten hebben. Het plan-Simons beoogde door een functionele omschrijving van rechten de rigiditeit van het huidige systeem te doorbreken en mogelijkheden te scheppen voor flexibiliteit en nieuwe voorzieningen. Nog steeds worden de rechten van verzekerden in de polissen omschreven in termen van voorzieningen.

Kwamen nieuwe ontwikkelingen voorheen op gang door deze eerst de status van experiment te geven, vervolgens het experiment te evalueren en daar bij voldoende succes geld voor vrij te maken, op dit moment draagt zo'n strategie te veel het risico in zich dat er ondanks goede resultaten geen vervolg komt.

Ondanks alle problemen komen er toch nieuwe vormen van zorg tot stand. Het gevoel dat zaken anders kunnen worden geregeld, de financiële druk en de duidelijke roep van de kant van chronisch zieken om nieuwe vormen van zorgverlening maken mensen en 
organisaties creatief. Telkens blijkt hoe essentieel het is dat de regionale zorgverlener zich actief yoor de zorgvernieuwing wil inzetten.

\section{INTEGRATIE VAN GENEESKUNDIGE ZORG}

Nu de voornaamste trends aan vraag- en aanbodzijde zijn geschetst, kan de integratie van de geneeskundige zorg voor chronisch zieken concreter worden uitgewerkt.

Belangrijk is hoe de extra- en intramurale sector zich willen ontwikkelen. Immers, één van de scenario's die hierover zijn gemaakt is het ontvlechtingsscenario met betrekking tot het ziekenhuis, waarin het denkbaar wordt geacht dat de specialist zelfstandig in en buiten het ziekenhuis zorg gaat geven. Zoiets zou tot verdere fragmentarie leiden. Na het voorafgaande zal duidelijk zijn dat ik vind dat een verdere ontwikkeling van ontvlechting het belang van de patiënt niet dient en daarom als ongewenst moet worden beschouwd. Voor chronisch zieken is het meer aangewezen de ontwikkeling te stimuleren van een transmuraal circuit waarin de intra- en extramurale zorg als een samenhangend, complementair systeem wordt beschouwd en vanuit één organisatie wordt geregeld en waarin een integraal zorgaanbod wordt geleverd. ${ }^{68}$ Daarmee kan worden bereikt dat de verschiliende zorgsystemen op elkaar aansluiten, de taken worden verdeeld zodat overlap en leemtes worden voorkomen, en duidelijkheid en overeenstemming wordt bereikt over het doel en de inhoud van de behandeling. Het woord 'circuit' duidt op een zekere dynamiek, een van de problematiek afhankelijke beweging tussen intra- en extramuraal.

De laatste jaren is op verschillende zorggebieden de meest wenselijke vorm van organisatie nagegaan. Moet bijvoorbeeld de regie centraal, door het ziekenhuis, door de eerste lijn, ad hoc, of anderszins worden georganiseerd?

In het rapport 'Thuiszorg voor patiënten met kanker' is voor het laatste gekozen, en wel voor het gecoördineerde samenwerkingsmodel, waarbij verschillende instituties hun voorzieningen inzetten op basis van bestuurlijke afspraken. Voorgesteld wordt in ziekenhuis en eerste lijn coördinatoren aan te stellen. $\mathrm{Er}$ is sprake van een gedeelde verantwoordelijkheid, die - afhankelijk van het probleem - tijdens het zorgproces van de een naar de ander kan overgaan. Deze 'shared care' wordt niet vanuit één punt aangeboden en kan, afhankelijk van gemaakte afspraken, op uiteenlopende plaatsen worden verleend. ${ }^{70}$

Een voorbeeld uit de praktijk is het project 'Transmurale zorg' in Midden-Twente, waarin het Streekziekenhuis Midden-Twente en de Kruisvereniging Midden- en Noord-Oost Twente participeren." In een transmuraal model wordt hier specialistische verpleegkundige zorg op het gebied van diabetes mellitus, CARA, reuma en de stomaverzorging aangeboden. De bestuurlijke en financiële verantwoordelijkheid wordt door beide organisaties gedragen. De verwachtingen, doelen en produkten zijn helder geformuleerd en de evaluatie is geregeld. Het succes van het project blijkt uit het achterblijven van opnames en polikliniekbezoek. Voor een ziekenhuis is succes dus niet 
zonder risico. Het kan alleen verantwoord deelnemen als de regelgeving wordt veranderd en het wordt toegestaan de achteruitgang in produktie in te zetten voor de transmurale zorg.

Organisaties als een ziekenhuis en de thuiszorg kunnen gemakkelijk overeenkomsten sluiten. Een niet te onderschatten probleem voor het verder ontwikkelen van integratie tussen geneeskundige zorg tussen de eerste en tweedelijn is het maken van bindende afspraken met de heterogene groep huisartsen.

Zowel de Gezondheidsraad als het Streekziekenhuis Midden-Twente koos voor het model dat Godfroij heeft aangeduid als dynamische nerwerken. ${ }^{72}$

Een netwerk is een lichte vorm van organisatie voor de coördinatie van niet-gelijksoortige instanties of instanties met divergerende belangen. ${ }^{73}$ Een netwerk is geen tovermiddel voor succes. De kans van slagen wordt groter als er rekening wordt gehouden met een zogeheten actielogica van de participanten. Het lijkt ongepast, maar ook in de gezondheidszorg wordt het werkelijk handelen van de actoren bepaald door het verdedigen van de eigen autonomie, het veilig stellen van de hulpbronnen in de ruimste zin van het woord - denk aan het budget -, het vergroten van macht en het beperken van de eigen afhankelijkheid.

Een netwerk kan alleen slagen als de participanten ondanks alle moeilijkheden de meerwaarde van deelname inzien, bijvoorbeeld doordat zij dankzij het netwerk bepaalde resultaten kunnen bereiken die anderszins niet zijn te behalen. Netwerkvorming zal niet slagen als de eerste lijn zich op andere wijze bevredigend kan verzekeren van specialistische inbreng of de tweede lijn het niet noodzakelijk of zelfs schadelijk vindt om aansluiting op de eerste lijn te krijgen.

Essentieel is, dat de bestaande organisaties de wil hebben om transmurale zorg te verlenen en hiervan blijk geven door bestuurlijk, organisatorisch en financieel verantwoordelijkheid te dragen. Bestuurlijke afspraken en het delen van verantwoordelijkheid betekenen echter niet dat de organisatie zwaar moet worden opgezet; dat past immers niet in het principe van een netwerk. Als lichte organisatie functioneert een netwerk juist niet op basis van formele vertegenwoordiging, afspraken en spelregels. Het ontleent zijn dynamiek aan de personen die iets met elkaar willen, aan de wederzijdse afstemming, de informatieuitwisseling, het overleg, de koersbepaling en de flexibele actie.

Hoe komt zo'n netwerk tot stand? Het hoeft nauwelijks betoog dat dit in een weerbarstig veld als de gezondheidszorg een behoedzame, plan- en bedrijfsmatige aanpak vergt. Schrijvers en Van Londen beschrijven vijf voor de hand liggende fasen van een zorgvernieuwingsproject: ${ }^{74}$

1. initiatiefase: in kleine kring wordt men zich bewust van de noodzaak van zorgvernieuwing;

2. adoptiefase: anderen dan bedenkers worden voor het idee gewonnen; 
3. fase van doelbepaling en instrumentontwikkeling: een team van betrokkenen gaat de plannen uitwerken;

4. experimentele fase: de ideeën worden experimenteel uitgetest;

5. realisatiefase: het project wordt een reguliere voorziening.

\section{CONCRETISERING}

Kenmerkend voor de subregio van Maastricht is de aanwezigheid van én ziekenhuis en de status van dit ziekenhuis als academisch ziekenhuis. Als academisch ziekenhuis heeft het azM specifieke taken op het gebied van de topklinische zorg, terwijl het als enig lokaal ziekenhuis tegelijkertijd de taak heeft gewone medische zorg in de regio te verlenen. Bijzonder aan onze situatie is bovendien dat de faculteit zich vanaf haar oprichting gericht heeft op het extramurale veld en daartegenover ook een speciale verplichting heeft. Het is begrijpelijk dat het ziekenhuis een groot deel van zijn capaciteit wil inzetten voor topklinische zorg. Topklinische zorg vergt door zijn aard veel voorzieningen en is daardoor duur. Deze situatie maakt het extra aantrekkelijk om het ziekenhuis te ontlasten door transmurale zorg te stimuleren. Door middel van het DCC zijn de Maastrichtse huisartsen al op diverse wijzen bij transmurale projecten betrokken. De Regionale Huisarts Vereniging participeert al in de Stuurgroep Transmurale Zorg. Dit laatste geldt tevens voor de Kruisvereniging Heuvelland, die reeds vertrouwd is met verpleegkundig specialisten en gespecialiseerde verpleegkundigen en de ambitie heeft uitgedrukt om transmuraal te werken. Ook vanuit Synchron wordt getracht transmurale samenwerking te stimuleren. De initiatiefase is dus ruimschoots gepasseerd.

In de adoptiefase gaat het om de diffusie van bestaande ideeën. Hiervoor is een reeks van activiteiten nodig met als oogmerk dat het zorgveld, dat wil zeggen het ziekenhuis, de daarvoor in aanmerking komende specialisten, de huisartsen en de kruisorganisatie, in overleg met vertegenwoordigers van de patiënten, overeenstemming bereikt over doel en middelen. Uitdagend en werkelijk vernieuwend lijkt het mij, de voorzet van Nieuwenhuijzen Kruseman serieus te nemen en te bekijken hoe op deelgebieden getrainde (wijk)verpleegkundigen een grotere rol kunnen vervullen in de geneeskundige zorg voor chronisch zieken en tot taakafbakening met huisartsen en specialisten kunnen komen.

Inmiddels zijn we in de fase van doelbepaling en instrumentontwikkeling. Doel zou kunnen zijn de patiënt een zoveel mogelijk op hem of haar toegesneden geïntegreerd pakket aan zorg aan te bieden. Naast het middel van de coördinerende verpleegkundige zijn middelen:

- de patiënt te behandelen op het laagste niveau waar dic verantwoord is, dus waar mogelijk horizontale en substitutie te bevorderen;

- te zorgen voor inhoudelijke, organisatorische en administratieve aansluiting van de zorgsystemen;

- te zorgen voor evaluatie op kwaliteit, inclusief effectiviteit en doelmatigheid. 
Stel, dat de intra- en extramurale organisaties voor de principes voor dit idee te winnen zijn, dan is het denkbaar dat zij een nenverkorganisatie oprichten. De regionale verzekeraar moet vanaf het begin bij het project worden betrokken.

Het ligt voor de hand dat het reeds aanwezige coördinatiecentrum tussen intra- en extramuraal, het DCC, als aansturende organisatie voor de zorgverlening gaat functioneren. Het DCC hoeft niet zelf als nieuwe intermediaire uitvoerende organisatie te gaan fungeren en zelf zorg te gaan verlenen, maar zorgt voor het opstellen van protocollen en zorgplannen, het coördineren van de intra- en de extramurale zorgverlening en van de evaluatie. De organisatie zal niet alleen licht, maar ook flexibel moeten zijn. De patiënten en ziektebeelden lopen zo uiteen dat de taken van de verpleegkundige, de specialist en de huisarts niet steeds gelijksoortig kunnen zijn. De flexibiliteit moet ook de patiënt en de betrokken hulpverlener betreffen. In eerste instantie komen patiënten in aanmerking met een aandoening met voldoende prevalentie om transmuraal ervaring op te bouwen en van voldoende ernst om transmurale zorg te rechtvaardigen, die in een stabiele fase van de ziekte verkeren en die voor onderzoek en/of behandeling niet sterk afhankelijk zijn van ziekenhuistechnologie.

Het is onproduktief om van elke huisarts hetzelfde te verwachten. Praktisch stel ik me voor, dat vanuit het coördinatiecentrum aan gezondheidscentra of huisartsgroepen het aanbod voor coördinatie van transmurale zorg aan gedefinieerde groepen patiënten wordt gedaan. Dit aanbod omvat bijvoorbeeld hulp bij de protocollering, bij het opstellen van een zorgplan, bij het verdelen, uitvoeren en bewaken (!) van zorgtaken, bij sociaalmedische begeleiding, bij registratie en administratie. De exacte invulling wordt van de specifieke situatie afhankelijk gesteld. Bij een ontwikkelingsmodel past, dat eerst met een beperkt aantal aandoeningen en praktijken ervaring wordt opgedaan, maar dat wel wordt gezorgd voor een zodanige terugkoppeling naar de participerende organisaties dat later diffusie van kennis en ervaring mogelijk is.

$\mathrm{Er}$ is nog niet veel ervaring met andere dan kleinschalige ontwikkelingsprojecten. Een goede wetenschappelijke evaluatie is daarom essentieel. Omdat het vergelijkend onderzoek waarmee wij in de geneeskunde vertrouwd zijn niet in aanmerking komt, moet de evaluatie starten vanaf het moment dat het project begint en moet zij een nulmeting bevatten. De evaluatie moet op de doelstellingen van het project zijn afgestemd en zowel de uitkomsten, de kosten-effectiviteit als het proces bevatten. Dit soort evaluatieonderzoek moet multidisciplinair worden opgezet.

Het zou fraai zijn als in enkele contrasterende regio's met een ontwikkelingsmodel voor transmurale zorg kan worden geëxperimenteerd.

Mijnheer de Rector, Dames en Heren,

Ruim elf jaar geleden heb ik aan de Vrije Universiteit een oratie gehouden over de individuele patiëntenzorg. De persoonlijke relatie van de dokter tot de patiēnt en de integrale zorg stonden hierin centraal. ${ }^{75}$ De term 'zorg op maat' drukt slechts in de verte 
uit wat ik daarvan vind. Individuele patiēntenzorg is en blijft mijn eerste liefde.

Vandaag heb ik gesproken over voorwaarden om op het individu toegesneden zorg te kunnen geven. Ruim honderd jaar geleden bleek in Amsterdam al dat wie de gezondheidstoestand van patiēnten wil optimaliseren niet voorbij kan gaan aan de structuur en organisatie van de medische zorg. Ik heb dit vandaag ingevuld door een andere vorm van zorg voor chronisch zieken voor te stellen waarbij een nieuwe invulling wordt gegeven aan het sleetse begrip 'continuïteit' en bovendien heb ik willen aangeven dat het niet om de dokter gaat. Vandaar mijn suggestie, dat artsen enige vanzelfsprekende posities opgeven door zich op sommige punten uit het primaire proces terug te trekken ten gunste van verpleegkundigen. Dat niet iedereen een dergelijk idee direct zal omarmen, begrijp ik goed.

De tweede les uit Amsterdam was, dat beleid pas praktijk kan worden als het wordt gedragen door patiënten en uitvoerders van zorg. Een inhoudelijk en organisatorisch ambitieus model voor transmurale zorg kan alleen worden ingevoerd met daartoe gemotiveerde instellingen, artsen, verpleegkundigen, patiënten en wetenschappers. Het moet in de eerste plaats door de direct betrokkenen worden gewild, gedragen en getrokken.

De omvang van mijn taak en mijn positie in de regio maken dat mijn bijdrage in Maastricht slechts bescheiden kan zijn. Ik verbeeld me dan ook niet dat ik in staat ben hier iets groots tot stand te brengen. $\mathrm{U}$ mag van mij verwachten dat ik mijn bekendheid met het veld en de landelijke ontwikkelingen naar vermogen gebruik om processen te faciliteren. Of dit lukt, zal in mei 1999 - als de externe financiering van de leerstoel ophoudt - blijken.

Aan het einde van mijn oratie gekomen wil ik een ieder bedanken die heeft bijgedragen aan de instelling van deze leerstoel. Graag wil ik hierbij noemen het College van Bestuur van de Rijksuniversiteit Limburg, de leden van het bestuur van de Faculteit der Geneeskunde, het bestuur van het Academisch Ziekenhuis Maastricht en in het bijzonder de leden van de Adviesgroep voor het Stimuleringsprogramma Gezondheidsonderzoek (SGO) die de leerstoel financiert. Daarnaast wil ik mijn werkgever, de Koninklijke Nederlandsche Maatschappij tot bevordering der Geneeskunst, en het bestuur van Medisch Contact danken dat zij bereid waren mij part-time voor de werkzaamheden alhier vrij te maken.

De collegae uit de vakgroep Interne Geneeskunde wil ik danken voor de uiterst collegiale wijze waarop ik in hun midden ben opgenomen. Het bestuur van het Diagnostisch Coördinerend Centrum bedank ik voor het 'thuis' dat mij wordt geboden. Afkomst verraadt zich altijd, daarom zie ik in het bijzonder uit naar de samenwerking met de vakgroep Huisartsgeneeskunde.

De afgelopen maanden heb ik geprobeerd met zoveel mogelijk hulpverleners en instanties in de regio kennis te maken. Ik kan onmogelijk iedereen noemen, maar de vermelding van 
de Regionale Huisarts Vereniging, de kruisvereniging Heuvelland, het Integraal Kankercentrum Limburg en het coördinatiecentrum chronisch zieken Synchron is op zijn plaats.

Ik wil geen lange lijst personen bedanken, maar meen een uitzondering te moeten maken voor mijn leermeester en promotor Van Es, de oprichter van het DCC en mijn 'proxy' collega Pop, de voorzitter van de vakgroep Interne Geneeskunde, Nieuwenhuijzen Kruseman, en de collegae uit de praktijk, waar ik zo graag aanwezig en zo vaak afwezig was, Kievit en Koopman.

Het is gebruikelijk in een oratie studenten te vermelden. Helaas brengt het Maastrichts systeem met zich mee dat het voor een partime hoogleraar niet gemakkelijk is actief betrokken te zijn bij het onderwijs. Ik verzeker $U$ echter dat het medisch onderwijs mij ter harte gaat. Ik hoop dan ook dat er wegen worden gevonden waarlangs ik betrokken kan raken bij de vorming van $U$, studenten aan deze Faculteit der Geneeskunde.

Tenslotte wil ik memoreren dat ik een nieuwe uitdaging ben aangegaan, maar dat dit voor Dingena, Maarten, Jaap en Marieke betekent dat ik nog minder bij hen ben. Ik dank jullie geduld met mij.

Ik heb gezegd.

Nieurgein, december 1994 


\section{Literatuur}

1. Verdoorn JA. Volksgezondheid en sociale ontwikkeling. Utrecht/Antwerpen; Uitgeverij Het Spectrum, 1965.

2. RIVM. Volksgezondheid Toekomst Verkenning: de gezondheidstoestand van de Nederlandse bevolking in de periode 1950-2010. Den Haag: Sdu Uitgeverij Plantijnstraat, 1993.

3. Nota 2000. Tweede Kamer der Staten Generaal, vergaderingen 1986-1987, 19500 nrs 1 en 2.

4. Staatssecretaris van Welzijn, Volksgezondheid en Cultuur. Chronisch-Ziekenbeleid; chronisch patiënten niet buitenspel. Brief aan de Tweede Kamer, vergaderjaar 1990-1991, kamerstuk 22025.

5. Commission on chronic illness. Chronic illness in the United States. Volume I: Prevention of chronic illness. Cambridge (Mass): Harvard University Press, 1957.

6. Es JC van. Patiënt en huisarts. Utrecht: Bohn, Scheltema \& Holkema, 1980: 98-9.

7. Voorn Th B. Chronische ziekten in de huisartspraktijk. Nijmegen, 1993. Academisch proefschrift.

8. Beckerman H, Bennekom CAM, Jelles F, Lankhorst GJ. Revalidatiegeneeskundig onderzoek bij chronisch zieken. Zoetermeer: Nationale Commissie Chronisch Zieken, 1994.

9. Commission on Chronic Illness. Chronic Illness in the United States. Volume I: Prevention of chronic illness. Cambridge (Mass): Harvard University Press, 1957.

10. World Health Organization. Targets for Health for All; Targets in support of the European Regional Stategy for Health for All. Copenhagen: World Health Organization Regional Office, 1985.

11. Bos GAM van den, Lenior ME. Sociale ongelijkheid en chronische aandoeningen, beperkingen en zorggebruik. Amsterdam: Instituut voor Sociale Geneeskunde, Universiteit van Amsterdam, 1991.

12. Haveman HB. Health for all by the year 2000. Rapportage Nederland 1994. Rijswijk: Ministerie van Welzijn, Volksgezondheid en Cultuur, 1994.

13. Fries JF, Capro LM. Vitality and aging. San Francisco: Freeman, 1981.

14. Fries JF, Green LM, Levine S. Health promotion and the compression of morbidity. Lancet 1989; i : 481-3. (Ned. vertaling: Gezondheidsbevordering en 'comprimering' van de morbiditeit. Medisch Contact 1989; 44: 1387-90.) 
15. Maas PJ van der. Vergrijzing en volksgezondheid. In: Es JC van, et al. Het Medisch Jaar 1989. Utrecht/Antwerpen: Bohn, Scheltema \& Holkema, 1989.

16. Schellevis FG. Chronic diseases in general practice. Nijmegen, 1993. Academisch proefschrift.

17. Velden $\mathbf{J}$ van der, Bos GAM van den, Schellevis FG, Ammers E van. Comorbiditeit. In: RIVM. Volksgezondheid Toekomst Verkenning: de gezondheidstoestand van de Nederlandse bevolking in de periode 1950-2010. Den Haag: Sdu Uitgeverij Plantijnstraat, 1993: 146-51.

18. Townsend P. Davidson N. Inequalities in health: the Black report. Middlesex: Pinguin, 1982.

19. Blane D, Smith GD, Barley M. Social class differences in years of potential life lost: size, trends, and principal causes. Br Med J 1990: 301; 429-32.

20. Bos GAM van den. Zorgen van en voor chronische zieken. Utrecht/Antwerpen: Bohn, Scheltema \& Holkema, 1989.

21. Bos GAM van den. Van oude mensen; de dingen die niet voorbijgaan. Amsterdam, 1993. Oratie Universiteit van Amsterdam.

22. Bos GAM van den. Onderzoek naar de gevolgen van chronische aandoeningen voor de gezondheid. T Soc Gezondheidsz 1991; 69: 237-41.

23. Montfort APWP van. Transmurale Zorgverlening in Nederland. Voordracht voor het congres 'Het overbruggen van de grenzen tussen thuiszorg en intramurale zorg'. Maastricht, 6 oktober 1994.

24. Kodner DL. Chronic illness: The 'new' health care paradigm. Keynote address presented at SYSTED 94, Geneva, 5th of May 1994.

25. Borst-Eilers E. Chronic diseases and health care policy. TSG/Gezondheid \& Samenleving 1993; 71, nr 4 (supplement): 19-20.

26. Duijnstee MSH, Cuijpers WJMJ, Humbert MJ, Dungen AWL van den. Mantelzorg voor mensen met een chronische ziekte. Zoetermeer: Nationale Cormmissie Chronisch Zieken, 1994.

27. Es JC van. Maatschappelijk bepaalde belasting van hulpzoekenden in de huisartspraktijk. Ned Tijdschr Geneeskd 1981; 125: 1641-5.

28. Spreeuwenberg C. De toegankelijkheid van het ziekenhuis. Metamedica $1981 ; 61$ : 204-19.

29. Cox C, Peeters-Niemantsverdriet S, Philipsen H, Neumann M, Campen C van, Huyer-Abu Saad C. Discontinuiteiten in de thuiszorg: aantasting van de kwaliteit van zorg? Den Haag: Gebied Medische Wetenschappen NWO, 1994. 
30. IJzermans CJ. Continuïteit in de zorg: realiteit of mythe? Huisarts Wet 1993: 36: 41-2.

31. Freeman G. Continuity of care in general practice: a review and critique. Fam Pract 1984; 1: 245-52.

32. Schouwstra K. De continuïteit. Een zorg voor de huisarts. Huisarts Wet 1976; 19: 386-90.

33. Querido JD. In een stadspraktijk. Utrecht: Wetenschappelijke uitgeverij Bunge, 1988.

34. Lamberts $H$. In het huis van de huisarts. Verslag van het transitieproject. Lelystad: Meditekst, 1991.

35. IJzermans CJ, Oskan SK. Continuïteit in de huisartspraktijk gemeten. Huisarts Wet 1990; 33: 51-6.

36. Nederlands Huisartsen Genootschap. Suggesties voor beleid inzake reumabestrijding. Brief aan de Staatssecretaris van Welzijn, Volksgezondheid en Cultuur. Utrecht, 26 september 1985.

37. Nederlandse Bond van Reumaverenigingen, Nederlandse Vereniging van Reumatologen, Nederlandse Vereniging voor Reumabestrijding. Beleidsmaatregelen en gerichte suggesties met betrekking tot knelpunten op het gebied van de bestrijding van reumatische aandoeningen en de gevolgen daarvan. Brief aan de staatssecretaris van Welzijn, Volksgezondheid en Cultuur. 's Gravenhage, 28 oktober 1985.

38. Nederlands Huisartsen Genootschap, Landelijke Huisartsen Vereniging. Brief aan de leden inzake preventie van osteoporose. Utrecht, oktober 1994.

39. Integrating primary and secondary care. London: National Health Service Managing Executive, 1991.

40. Kimball HR, Young PR. A statement on the generalist physician from the American Boards of Family Practice and Internal Medicine. JAMA 1994; 271: 315-6.

41. Financieel Overzicht Zorg 1995. Rijswijk: Ministerie van Volksgezondheid, Welzijn en Spor, 1994.

42. Rijdt-van de Ven AHJ van de. Huisarsengroepen, groei en grenzen. Tilburg: Tilburg University Press, 1994.

Zie ook: 'Veel is bereikt, maar de grenzen zijn nu in zicht' (interview). De Huisarts oktober 1994; 5: 67-70.

43. Commissie Structuur en Financiering Gezondheidszorg. Bereidheid tot verandering. Rijswijk: Ministerie van Welzijn, Volksgezondheid en Cultuur, 1987. 
44. Substitutie in de gezondheidszorg. Discussienota. Zoetermeer: Nationale Raad voor de Volksgezondheid, 1989.

45. Haan J de. De doktersassistente. Delegeren van taken in een huisartspraktijk. Lelystad: Meditekst, 1986.

46. Nijland A, Groenier $\mathrm{KH}$, Meyboom- de Jong $\mathrm{B}$ et al. Determinanten van het delegeren van (medisch-technische) taken van de praktijkassistente. Huisarts Wet 1991; 34: 484-90.

47. Elberse WP, Schrijvers AJP. Reumaconsulenten in Nederland. Utrecht: Vakgroep Algemene Gezondheidszorg en epidemiologie, RUU, 1992.

48. Jonker JJC, Rozendaal A. Twee jaars resultaten van het Diabetes Centrum Rotterdam (DCR). TGO 1988; 13: 209-19.

49. Nieuwenhuijzen Kruseman AC. Open cirkels. Inaugurele rede. Maastricht: Rijksuniversiteit Limburg, 1990.

50. Bos AME, Holwerda-Straver I, Leeuwen MA van, Rijswijk $\mathrm{MH}$ van. Reumaconsulente AZG; ontwikkeling, inventarisatie en evaluatie van de functie. Groningen: AZG, 1991.

51. Advies verpleegkundig specialist. Zoetermeer: Nationale Raad voor de Volksgezondheid, 1989.

52. Advies functiedifferentiatie in de verpleging. Zoetermeer: Nationale Raad voor de Volksgezondheid, 1990.

53. Hiddema S, Meulen $\mathbf{P}$ van der, Nieweg R. Hoekstra J. Verpleegkundig specialisten. Ervaringen in het Academisch Ziekenhuis Groningen. Tijdschrift voor Ziekenverpleging 1988; 42: 637-9.

54. Ketelaars C, Dam G ten. Gedifferentieerd en gespecialiseerd werken in de wijkverpleging. Assen/Maastricht: Dekker \& Van der Vegt/Van Gorcum, 1993.

55. Wissink H, Asbreuk A. transmuraal verpleegkundige voor de diabeteszorg. EADE Nieuwsbrief, augustus 1991.

56. Commissie modernisering curatieve zorg. Gedeelde zorg: betere zorg. Zoetermeer: Hageman bv, 1994.

57. Es JC van. Patiënt en huisarts. Utrecht: Bohn, Scheltema \& Holkema, 1980.

58. Schipper R, Gooszen HCh, Jansveld CAF et al. CARA in kaart. Medisch Contact 1988; 43: 1347-49.

59. Palmen FMLHG. CARA in kaart (brief). Medisch Contact 1989; $44: 42$.

60. Wildevuur SE. De NP/CF als 'derde' partij. Medisch Contact 1994; 49: 1419-21. 
61. Landelijke Huisarsen Vereniging. Brief aan de minister van Volksgezondheid, Welzijn en Sport. Utrecht, 16 november 1994.

62. Grinten TED van der, Huijsman R. Strategische opties voor een transmurale gezondheidszorg. Medisch Contact 1994; 49: 1394-8.

63. Beijaer RPH, Hiemstra Y, Hoogvliet G, et al. Thuiszorgtechnologie. Utrecht: Nederlands Huisartsen Genootschap, 1993.

64. Richtlijn infusietechnieken bij pijnbestrijding thuis. Utrecht: Vereniging van Integrale Kankercentra, 1994.

65. Boom $\mathrm{F}$ van den. Chronisch-zieken beleid: het zoeken naar een mix van sturing, bijsturing en zelfsturing. Voordracht symposium 'Zorg, opvang en begeleiding' georganiseerd door de NCCZ te Ede op 2 juni 1994.

66. Bakker DH de, Peters P, Sluijs EM, Philipsen H. Kwaliteit van zorg en zorgvernieuwing. 's Gravenhage: Gebied Medische Wetenschappen NWO, 1994.

67. Projectgroep o.l.v. Zwan A van der et al. Gezondheidszorg in tel 2. Utrecht: NZf/NZi, 1994.

68. Boersma WGW, Bakker DH de, Groenewegen PP, et al. Scenario's voor eerstelijnszorg en thuiszorg. Medisch Contact 1992; 47: 378-81.

69. Thuiszorg voor patiënten met kanker. 's Gravenhage: Gezondheidsraad, 1991.

70. Orton P. Shared care. Lancet 1994; 344: 1413-5.

71. Transmurale Zorg in Midden Twente. Hengelo: Streekziekenhuis Midden Twente en Kruisvereniging Midden- en Noord-oost Twente, 1991.

72. Godfroij AJA. Dynamische netwerken. M\&O, Tijdschrift voor Organisatiekunde en Sociaal Beleid 1992; 44: 365-75.

73. Glasbergen P. Beleidsnetwerken rond milieuproblemen. Een beschouwing over de relevantie van het denken in termen van beleidsnetwerken voor het analyseren en oplossen van milieuproblemen. 's Gravenhage: VUGA, 1990.

74. Schrijvers AJP, Londen J van. Enkele theoretische beschouwingen over het vernieuwen van zorg. Ned Tijdschr Geneeskd 1991; 135: 1502-6.

75. Spreeuwenberg C. Met het oog op de huisarts. Inaugurele rede. Vrije Universiteit Amsterdam, 1983. 